\title{
The role of savanna in nomadic pastoralism: some observations from western Bornu, Nigeria
}

\author{
P. N. DE LEEUW \\ Institute for Agricultural Research, Ahmadu Bello University, Samaru Zaria, \\ Northern Nigeria, Nigeria
}

\section{Summary}

The vegetation of western Bornu, Northern Nigeria, its environment, physiognomy and composition of the flora are described. This savanna vegetation has developed under the combined influence of a severe dry season, shifting cultivation, grazing and the resulting annual fires.

The savanna constitutes the grazing orbit of nomadic pastoralists who have adapted their system of cattle husbandry to the seasonal variation of the grazing land by a cyclic transhumance pattern of their families and herds.

\section{Introduction}

During 1960-62 vegetation studies have been carried out over an area of about $31,500 \mathrm{~km}^{2}$ in conjunction with a number of reconnaissance soil surveys in the Middle Gongola region.

During those surveys the following methods were employed: records were made at regular intervals along the survey traverses noting the physiognomy according to the classification of BOUGHEY (1953) and recording the abundance of each arboreal species in a four-point scale. To arrive at a quantitative assessment of the vegetation, half-acre plots were demarcated and fully enumerated in four diameter classes, each species separately. A representative coverage of all soil mapping-units was attempted. The total number of samples was 401 . During a subsequent survey the sample size was reduced to one-tenth acre $\left(132^{\prime} \times 33^{\prime}=40,2 \times 10,1 \mathrm{~m}\right)$ and the plots were laid out along a transect at regular intervals. This reduction of sample size was adopted as it is believed to provide a more accurate assessment of the mosaic pattern existing within most savanna vegetation. About 600 samples were enumerated following this method.

As all the surveys were carried out during the dry season, data on herbaceous growth could not be obtained. Most grasses and herbs are unidentifiable during this period and are often burned off altogether. As supplementary information on the herbs and grasses was desirable in view of the importance of the area for nomadic grazing, a range survey was carried out in the northern part of the main survey area from July to November 1964 .

The method employed consisted of recording the species composition in quadrats,

Received for publication 4th January, 1965. 
$0.25 \mathrm{~m}^{2}$ in size. The samples were arranged along a transect at $6 \mathrm{~m}$ intervals and the number of plots along a transect was $10,20,25$ or 50 depending on the homogeneity of the cover. In addition to species composition, cover in a ten-point scale and height of the most important species were recorded. As a quantitative measure the three most important species were ranked numerically (DE VRIES and DE BOER, 1959). Regularly all herbage within plots was cut and weighed to determine the correlation between cover and fresh weight. Throughout the field season samples of the more important range species were cut, weighed, sun-dried, packed in sealed plastic bags and sent to Samaru for chemical analysis. In total 2,500 quadrats were sampled.

A general description of the arboreal vegetation has been published in KLINKENBERo et al. (1963) and part of the quantitative data have been analysed by RAMSAY and DE LEEUW (1964). The present paper attempts to give a short outline of the arboreal and herbaceous vegetation in western Bornu and its utilisation under a system of nomadic pastoralism.

\section{Climate}

The rainfall increases from $625 \mathrm{~mm}$ in the north to about $1000 \mathrm{~mm}$ in the southern part of the survey area and follows a single-peak distribution. The mean monthly rainfall for three stations is given in TABLE 1; Potiskum is considered most representative for the greater part of the area. The rain is concentrated in a period from June to September with a peak in August. The length of dry season increases with diminishing rainfall: The number of dry months - i.e. less than $25 \mathrm{~mm}$ per month averages between 5 and 6 for Potiskum and Biu; while for Nguru a dry period of 7 to 8 is the most frequent (Pullan, 1962). The yearly variation in annual and monthly rainfall is considerable and increases to the north; for Nguru $50 \%$ of the records range between 475 and $625 \mathrm{~mm}$ with absolute values of 300 and $850 \mathrm{~mm}$.

The mean maximum temperature reaches a peak in April (Potiskum $39.0^{\circ} \mathrm{C}$ ) during the hot, humid period immediately proceeding the onset of the rains, gradually falls towards the middle of the rainy season, increases again at the end of the rains before falling to a second minimum in December and January (Potiskum $31.1^{\circ} \mathrm{C}$ ). The mean minimum temperature follows a single-peak pattern with a minimum during December to February and a peak during the rainy season.

During the dry season the winds come mainly from the east and north-east and are accompanied by a very low relative humidity (Potiskum: February-March: 17-18 \% at 9.00 hours). Southern and south-western winds prevail from May to September, the relative humidity during this period varying from 60 to $80 \%$.

\section{Soils}

The northern portion of the area forms an undulating drift-covered plain in which various residual dune patterns can be recognised (HOPE, 1963); extensive sandy flats alternate with hummocky terrain, while southwards irregularly-shaped dunes and depressions occur together with narrow longitudinal dunes which are arranged in a northeast-southwest direction. South of $12^{\circ} \mathrm{N}$ latitude the drift mantle gradually thins out and gives way to ferruginised exposures of pleistocene Chad sediments and the Eocene Kerri-Kerri formation; these formations consist of massive beds of clay, clayey grits, sand and silt. The relief is more pronounced; ironstone-capped tabular 
hills form distinct landmarks, whereas deeply dissected terrain marks the water divide between the Chad and Gongola-Benue Basins.

To the south and southwest extensive flat to undulating plains flank the Gongola river and its tributaries. They are underlain by Cretaceous sediments varying from sandstones to shale. The Biu basalt plateau occupies the south-eastern corner of the survey area. It rises to $700 \mathrm{~m}$ and consists of a generally flat plateau marked with cones, crater remnants, spurs and ridges. To the west the plateau descends to the Cretaceous plains by a steep escarpment.

The drift soils in the northern part are mainly deep, reddish-yellow to very palebrown sands to sandy loams containing a large proportion of fine sand. On the dune crests and slopes they are excessively drained; in the depressions the soils are greyer, somewhat heavier in texture and show impeded drainage, with intermittent or continuous flooding during the rainy season. TomLinson (1964) classifies them as ferruginous soils on sandy parent material.

In the transition zone between the eolian and sedentary deposits, the soils vary considerably in depth depending on the thickness of the drift mantle overlying the parent rock; stony shallow soils are predominant on scarps, slopes and hilltops, while in areas with a gentler topography deep, red to yellowish-brown, well-drained sands and loams are common.

The soils underlain by Cretaceous sediments vary according to topography and whether they are developed over sandstone, siltstone or shale. Light-textured and welldrained, often shallow sands and loams are found in dissected sandstone terrain; deep, poorly-drained, dark, cracking clays occupy the flat plains over shales. They form a complex mixture of ferruginous soils over sandstone and vertisols (TomLINSON, 1964).

On the Biu plateau the soils are often shallow and stony, in particular along the western escarpments and on the remnants of recent volcanic activity. Towards the centre of the plateau the soils become deeper and less stony; they vary from moderately deep reddish-brown loams on gentle slopes to deep, grey, cracking clays in "basin depressions". The soils over basalt belong to lithosols, eutrophic brown soils and vertisols (TOMLINSON, 1964; KLINKENBERg et al., 1963).

\section{Vegetation}

\subsection{In troduction}

Following the early ecological zonation of West Africa by Chevalier (1900), KeAY (1953b) divided Northern Nigeria in four zones, termed the Sahel, Sudan, Northernand Southern-Guinea Zones. On further ecological and floristic evidence, Clayton (1957) subdivided the Sudan zone into the true Sudan and the sub-Sudan zone. The survey area lies mainly in the Sudan and sub-Sudan zones apart from a small area on the Biu plateau, which belongs to the Northern-Guinea zone. The broad climatic limits of these zones are given in TABLE 2 .

To place the vegetation of the survey area within the wider setting of Africa as a whole, the ecological zones and their corresponding vegetation as classified by A.E.T.F.A.T. (1959) and RATTRAY (1960), are illustrated in TABLE 2.

These classifications are similar in that they differentiate the vegetation in broad physiognomic units, which, for the area under review, vary from wooded steppe to savanna woodland. Such physiognomic division takes in account the height and density of the arboreal and herbaceous cover and also whether the latter is mainly annual or perennial. It is worth mentioning that none of the classifications indicate the 
TABLE 2. Ecological zones and their vegetation classification

\begin{tabular}{|c|c|c|}
\hline $\begin{array}{c}\text { Ecological zones } \\
\text { KEAY (1953b), CLAYTON (1957) }\end{array}$ & A.E.T.F.A.T. (1959) & RATTRAY (1960) \\
\hline $\begin{array}{l}\text { S a h e } 1 \text { z o n e } \\
\text { Rainfall: } 500 \mathrm{~mm} \\
\text { No. of months }<25 \mathrm{~mm}: 8 \\
\text { Su d a } \mathrm{z} \text { o } \mathrm{n} \\
\text { Rainfall: } 500-1000 \mathrm{~mm} \\
\text { No. of months }<25 \mathrm{~mm}: 7 \\
\text { S u b-S u d a } \mathrm{n} \text { z o n e } \\
\text { Rainfall: } 750-1000 \mathrm{~mm} \\
\text { No. of months }<25 \mathrm{~mm}: 5 \\
\text { Nor t h e r }-\mathrm{G} \text { u i n e a z o n e } \\
\text { Rainfall: } 1000-1250 \mathrm{~mm} \\
\text { No. of months }<25 \mathrm{~mm}: 4-5\end{array}$ & $\begin{array}{l}\text { Wooded ste p pe } \\
\text { Acacia and Commiphora spp. } \\
\text { abundant } \\
\text { S a a n a wo o d land } \\
\text { Relatively dry types: } \\
\text { Combretum, Terminalia, } \\
\text { Adansonia, Sclerocarya } \\
\text { abundant }\end{array}$ & $\begin{array}{l}\text { C e } \mathrm{n} \text { h } \mathrm{r} \text { u t y } \mathrm{p} \\
\text { Associated with savanna grasses: } \\
\text { Cenchrus biflorus, } \\
\text { Eragrostis tremula } \\
\text { Pennisetum pedicellatum } \\
\text { Diectomis fastigiata } \\
\text { Ctenium elegans } \\
\text { Aristida longiflora } \\
\text { Andropogon gayanus } \\
\text { A n d o p o g o t y p } \\
\text { Low savanna grasses: } \\
\text { Andropogon gayanus } \\
\text { A. pseudapricus, } \\
\text { Hyparrhenia dissoluta, } \\
\text { H. rufa, H. cyanescens } \\
\text { Beckeropsis uniseta } \\
\text { Brachiaria jubata, } \\
\text { Monocymbium ceresiiforme, } \\
\text { Panicum dregeanum } \\
\text { Pennisetum polystachyon }\end{array}$ \\
\hline
\end{tabular}

hierarchical or successional status of the types; they show the vegetation as it is at present. It is generally accepted (A.E.T.F.A.T., 1959; LEBrun and GiLberT, 1954; Sillans, 1955) that the combined action of bush clearing, cutting of wood for fuel, browsing and grazing is responsible for the degradation of the arboreal cover and has resulted in the development of a vigourous herbaceous growth, which is highly combustible; the ensuing annual burnings together with recurrent clearing as practised in the system of shifting cultivation exert such influence that a more or less permanent "deflected sub-climax" is maintained. Full protection of the savanna vegetation, however, induces the tree canopy to become more dense and causes suppression of the grasses accompanied by a gradual change in composition of the flora such as the increase of fire-tender species in the undergrowth.

4.2. The arboreal vegetation 1

A sub-division of the broad physiognomic units in the survey area has been attempted (KLINKENBERG et al., 1963). Though it is possible (in the field) to recognise communities which are characteristic in physiognomy and species composition, their delimitation into distinct types and the grouping of those into units of higher status is difficult. It has been found that the majority of savanna species occur over large areas and show remarkable tolerance to a wide range of climatic and edaphic conditions. They are similar in their resistance to or tolerance of fire, and most of them are capable of regrowing from coppice or root suckers, a necessary means of survival against repeated burning, cutting and browsing. Savanna vegetation is therefore very homogeneous and consists of a mosaic pattern of seral communities at different stages

1 Nomenclature of aboreal species is according to: The flora of West Tropical Africa by J. HUTCHINSON and J. M. DALZIEL, London (1954-63) 2nd ed., revised by R. W. J. KEAY and F. N. HEPPER. Nomenclature of the Gramineae is according to: A key to Nigerian grasses (1960). Samaru Res. Bull. No. 1 by W. D. CLAYTON. 
of successional development after clearing. More distinct communities can be recognised on sites affected by adverse conditions but on which human interference is less intense (RAMSAY and DE LEEUW, 1964).

A short description of the major vegetation types in the survey area is given hereunder. The units are defined by their physiognomy and component dominants; it should be borne in mind however that the types are diffuse assemblages of trees and shrubs rather than well-defined associations.

1. Acacia senegal - Commiphora spp. low savanna woodland

This vegetation type consists of an open assemblage of trees and shrubs 3 to $8 \mathrm{~m}$ high and variable density over a mainly annual herbaceous stratum. Acacia senegal and Commiphora pedunculata are usually dominant; common species include Dalbergia melanoxylon, Sclerocarya birrea, Commiphora africana, Randia nilotica and Lannea schimperi. It is often intermixed with 2 to $3 \mathrm{~m}$ high shrubland in which Guiera senegalensis and Combretum glutinosum are the major constituents. This is the common vegetation on the drift-covered plains to the north of the Maiduguri - Potiskum road (FIG. 1). It appears that when protected, as in forest reserves, the upper canopy becomes higher and denser and a more diverse composition of the flora has been observed.

Although it is situated in the Sudan zone, the dominant species and the predominantly annual grass cover suggest a close affinity to a Wooded steppe (TABLE 2).

2. Mixed Anogeissus leiocarpus savanna woodland and tree savanna

This type predominates in the greater part of the survey area south of $12^{\circ} \mathrm{N}$ latitude; it is associated with the huge belt of Anogeissus savanna which stretches across from the Sudan to Dahomey in the transition between the Sudan and the Guinea zones.

Going from north to south there is a marked difference in the edaphic conditions under which it occurs. To the north it is restricted to relatively moist habitats: tall Anogeissus woodland is a common feature in inter-dune depressions and an open tree savanna consisting of dense thickets of Anogeissus and Acacia ataxacantha and other climbers on residual termitaria is characteristic of low-lying, poorly-drained flats. Towards the south the type includes 10 to $15 \mathrm{~m}$ high open savanna woodland of mixed composition in which tall trees such as Bombax costatum, Sterculia setigera, Lannea schimperi, Lonchocarpus laxiflorus are common. These relatively "mature" types are frequent in forest reserves and other areas that have escaped farming. In more recently disturbed sites tree savanna occurs with large patches of secondary shrub savanna. It appears that, when situated within its optimal climatic range of occurence, the type shows little preference for edaphic conditions although it is not found either on shallow, stony sites or on poorly-drained soils.

3. Detarium - Boswellia - Afrormosia savanna woodland

This type is found almost exclusively on shallow, stony soils and as such is the typical vegetation on steep slopes, scarps and hill-tops. Detarium microcarpum and Boswellia dalzielii are the dominant trees in the 10 to 15 high upper canopy; the major constituents in the lower stratum include Afrormosia laxiflora, Crosopteryx febrifuga and Combretum glutinosum. This type is found widely on similar sites throughout the sub-Sudan zone.

4. Acacia seyal savanna woodland and tree savanna

An open, often regularly-stocked 6 to $10 \mathrm{~m}$ high savanna woodland or tree savanna with Acacia seyal as the single dominant, is characteristic of the shale plains with deep, cracking, dark clays. Associated species are Acacia campylacantha and Balanites aegyptiaca. A dense perennial grass cover up to $3 \mathrm{~m}$ high with occasional patches of scandent shrubs in thickets forms the undergrowth, which during the dry season gives rise to fierce bush-fires. This edaphically induced fire-climax vegetation is extensively found throughout the savanna zones of Africa.

5. Mixed Isoberlinia doka savanna woodland

Evenly-stocked, 12 to $15 \mathrm{~m}$ high stands of pure Isoberlinia doka are confined to the stony slopes and scarps of the Biu plateau. In most instances, however, it is intermixed with Boswellia dalzielii, Butyrospermum parkii and Lannea schimperi, and after human interference it is replaced by a low tree savanna of Boswellia, Acacia senegal and Combretum glutinosum. It is similar to the 
Isoberlinia woodlands in the central and western part of the Northern-Guinea zone, but many of the associated species given by KEAY (1953a) are absent.

\section{Secondary shrubland}

The pioneer communities that occupy abandoned farmland consist of quick-growing shrubs such as Combretum glutinosum, Guiera senegalensis, Ziziphus mauritiana, Dichrostachys glomerata and others (FIG. 2). When after a few years, a 2 to $3 \mathrm{~m}$ high shrub cover has been established, Combretum and Terminalia spp. which easily regrow from coppice become increasingly prominent. With time the species composition becomes more heterogeneous and in general tends to approach the pre-cultivation vegetation. In areas where the demand for land is great, the fallow period is reduced in consequence and shrubland dominated by a few emergent tree species becomes a permanent feature.

\subsection{The herbaceous vegetation}

The following description of the herbaceous cover only includes the more distinct types of grassland communities and ignores the many transitional variants which were observed and recorded during the field survey. The types described may be considered as a first approximation of the grass communities in western Bornu. Little attention has been paid to the successional relationships that may exist between the communities. An analysis of that nature will demand a statistical processing of data which has not yet been attempted.

\section{Brachiaria xantholeuca type}

Low (40-80 cm high), open, largely annual grassland occupies the open, low tree savanna with Acacia and Commiphora on freely-drained aeolian sands. It extends far to the north and is characteristic on the wide undulating dunes carrying a predominantly Guiera shrubland between Lantewa and Gashua (FIG. 1). Its species composition includes Dactyloctenium aegyptiaca, Digitaria gayana, Zornia diphylla and a large proportion of weeds, while Pennisetum pedicellatum is prominent in the shade of trees and shrubs. The composition of the flora suggests an affinity to pioneer communities that become established after cultivation; transitional types in which Cenchrus biflorus, Schizachyrium exile and Diheteropogon hagerupii are common are often encountered. A successional development with age towards a Loudetia type appears to exist in the Loudetia belt. To the north of the $12^{\circ} \mathrm{N}$ latitude such a trend has not been observed and it is probable that there the Brachiaria type constitutes a more or less stable community.

Its grazing value is low, although in the earlier part of the wet season some of the annuals are eaten; Pennisetum, however, forms the major fodder; Andropogon gayanus var. bisquamulatus is locally common and heavily grazed, while towards the north Anthephora nigritana, a perennial tussock grass, is the preferred fodder species.

\section{Loudetia togoensis type}

This type forms a low (up to $1 \mathrm{~m}$ ), open, annual-grass community in which Loudetia togoensis is the dominant species; it covers large stretches of country in the survey area. It occurs in the treeless patches of Anogeissus savanna as well as in the open shrublands with Acacia, Commiphora, Combretum and Guiera. Its optimum range of occurence lies between $11^{\circ} 30^{\prime} \mathrm{N}$ and $12^{\circ} 30^{\prime} \mathrm{N}$ latitudes. Its occurence in relation to soil conditions is hard to define as it grows on well-drained, deep eolian sands, deep sandy loams over sandstone, shallow, stony soils on steep slopes and occasionally on temperarily flooded sites in the inter-dune depressions. Its main habitat factors seem to be full exposure, annual and early burning and probably the incidence of a self-sealing soil surface inducing a low infiltration rate and consequent sheet-wash during heavy rains.

The general aspect of the type is very uniform. Common species are Sporobolus festivus, $S$. granularis, Digitaria gayana, Brachiaria xantholeuca and Andropogon gayanus var. bisquamulatus. On moister sites A. pseudapricus, Diectomis fastigiata and Brachiaria stigmatisata are prominent. As a range it is of poor quality as most species, except $A$. gayanus, are of low palatability. Loudetia and most of the annuals flower in August and dry up during September; burning starts immediately after the cessation of the rains (FIG. 3). 
Fig. 2. Shrub savanna with Guiera senegalensis, Schizachyrium exile, Pennisetum pedicellatum and tussocks of Andropogon gayanus var. bisquamulatus

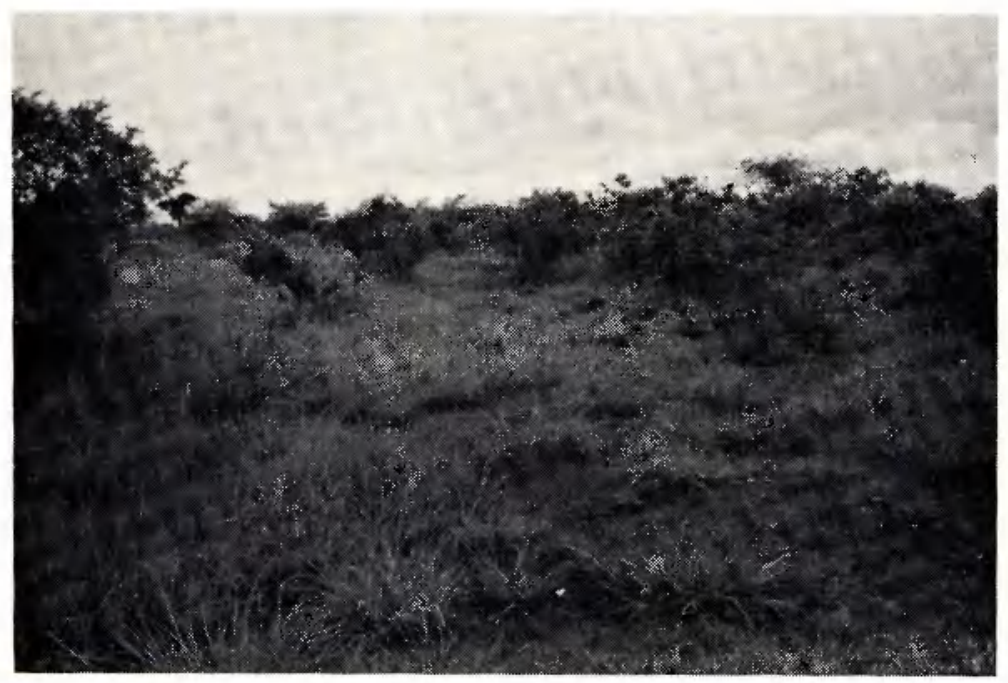

FIG. 3. Open, low savanna woodland with Anogeissus leiocarpus; burned Loudetia togoensis alternates with Pennisetum pedicellatum around trees

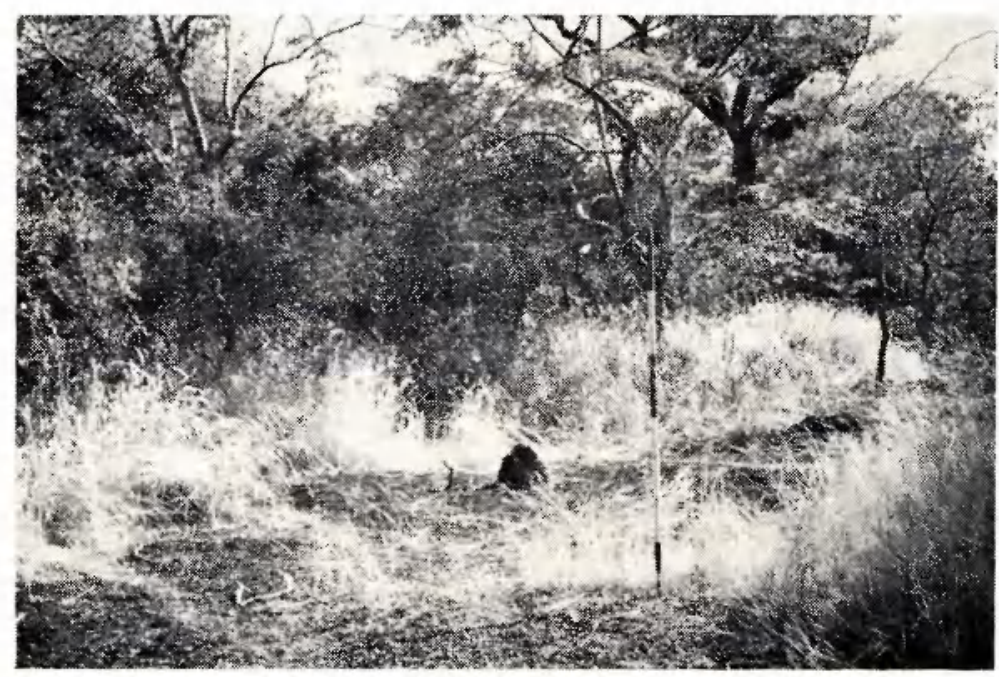


squamulatus and var. squamulatus are irregularly distributed throughout the type, the latter often near trees, growing together with Pennisetum pedicellatum, Rottboellia exaltata, Bracharia lata and B. deflexa.

On the Biu plateau similar communities occur under open tree savanna on flat areas with deep, grey-brown loam and clay loam which are often imperfectly drained. In this more southern locality the type seems a transitional phase between pioneer communities on fallow land and a 1.5 to $2 \mathrm{~m}$ tall perennial grassland of Andropogon gayanus var. bisquamulatus and squamulatus and $A$. schirensis. It includes a variant with Aristida spp. and Loudetia togoensis which follows prolonged overgrazing and a moister variant with Hyparrhenia rufa, $\boldsymbol{H}$. diplandra, $\boldsymbol{H}$. filipendula and Brachiaria jubata.

The dominant species flower in September and become dry towards the middle of Octobre. $H$. soluta is grazed when young, but the value of the type depends on the proportion of perennial species many of which remain green far into dry season.

4. Pennisetum pedicellatum type

The occurrence of $P$. pedicellatum is conditioned solely by the presence of shade and it generally grows in a mosaic pattern with a large number of other types. As it is confined to the vicinity of tree and shrubs, its occurrence is directly related to the density of the arboreal growth, so that in some of the denser Anogeissus woodlands it forms almost continuous pure swards 50 to $70 \mathrm{~cm}$ high. Although its distribution is very wide, optimal growth appears to be confined to the Sudan zone; in this zone it occupies all soils and sites except those that are poorly drained or flooded. Towards the south its growth is less vigourous and it is often replaced by Andropogon spp. and Rottboellia.

Being a broad-leaved, succulent and nutritious grass, it is heavily grazed during the wet season. It can endure a moderate intensity of grazing and regrows easily; cattle prefer it to all other grasses except Andropogon gayanus var. bisquamulatus and those two species provide most of the grazing in the drier part of the western Bornu savanna. It flowers from the middle of September and withers from November onwards (FIG. 3).

5. Andropogon gayanus - Diheteropogon hagerupii type

An open tree savanna with perennial, dense, tussocky grass cover up to $3 \mathrm{~m}$ high is characteristic of the steep basalt cones and crater remnants. It occurs also on the higher parts of the plateau near Biu town on terrain that has been allowed to lie fallow for a long time. The main species include A. gayanus var. squamulatus, Diheteropogon, A. schirensis, Cymbopogon giganteus and occasionally Beckeropsis uniseta. Under regular grazing the type provides good fodder until the beginning of December.

The slopes of lesser gradient have usually been farmed and often terraced; the perennial grass cover on such land is replaced by an open annual cover of Heteropogon contortus, Loudetia acuminata, Schizachyrium exile, $S$. schweinfurthii, S. sanguineum and Ctenium newtonii.

6. Hyparrhenia rufa - Setaria sphacelata type

In the Acacia hockii shrub savanna, which is typical of the poorly-drained clay basins on the Biu plateau, the grass stratum consists mainly of tussocks of Setaria up to $1 \mathrm{~m}$ high. Additional species are Sorghum purpuro-sericeum, Hyparrhenia diplandra and Scleria spp. Hyparrhenia rufa becomes a member of these communities on the better-drained sites and becomes dominant along valleys forming a stratum, 2 to $3 \mathrm{~m}$ high. If the basins have been previously farmed, Hyparrhenia soluta var. violascens may be predominant. Setaria and $H$. diplandra are palatable and the type is grazed during the early months of the dry season.

7. Echinochloa spp. type

A tall grass community dominated by $E$. obtusiflora is characteristic on the cracking clays derived from shales which carry an Acacia seyal tree savanna. Other constituents include Andropogon gayanus var. squamulatus, Sorghastrum bipennatum and Schoenefeldia gracilis. It appears that on better-drained sites which usually carry an Acacia seyal - A. campylacantha tree savanna, the E. obtusiflora type is replaced by a Brachiaria mutica, A. gayanus var. squamulatus and Sorghum purpuro-sericeum grassland up to $3 \mathrm{~m}$ tall.

Similar communities are found on alluvial clay basins, flood plains and temporary swamps. Drainage conditions and the duration and depth of flooding are the main factors contributing to the variety of grass communities found. E. obtusiflora, E. pyramidalis, E. stagnina, Panicum subalbidum, 
$P$. anabaptistum, $P$. leatum and Schizachyrium brevifolium are the more important species. Although except for $P$. anabaptistum most grasses are coarse and fibrous, they form an essential source of forage during the latter part of the dry season.

8. Oryza spp. types

Aquatic grassland with $O$. barthii, and to a lesser extent $O$. breviligulata, is typical of the deeper parts of swamps that are flooded for the greater part of the wet season. Grassland with $O$. barthii and Vetiveria nigritana occupies the flood plains of the larger streams. These types are usually fringed by the Echinochloa spp. and associated communities.

9. Fallow types

A large variety of pioneer communities establish themselves after farmland is left to fallow. They are open (cover 5 to $10 \%$ ), low (up to $1 \mathrm{~m}$ ) grass and herb communities often of rich and varied species composition. Cenchrus biflorus, Dactyloctenium aegyptiaca, Brachiaria xantholeuca, Digitaria adscendens, Schizachyrium exile and Pennisetum pedicellatum are among the more common annuals in the Sudan zone on eolian drift. Towards the south and in particular on the Biu plateau a successional development from Pennisetum pedicellatum to Hyparrhenia soluta var. violascens has been observed on deep, heavy-textured soils.

\section{Cattle husbandry}

\subsection{Introduction}

It is estimated that there are about eight million cattle in Northern Nigeria, more than $90 \%$ of which are owned by Fulani (FIG. 4 and 5). This figure is based on the yearly cattle-tax returns and, if allowance is made for the customary evasion of this tax, a much higher total would emerge. During the rainy season more than half of the herds are concentrated in the tsetse-free zone which stretches in the north over a belt 140 to $220 \mathrm{~km}$ wide. During the dry season, the majority of cattle leave this zone and are driven to the south in search of fodder and water, thereby penetrating deeply into fly-infested country. Their movements are directed towards the Middle Belt and in particular to the flood plains of the major rivers. At the onset of the rains the north-bound trek commences and around June to July most herds have returned to their wet-season range in the north.

The increasing demand for farmland, due to the growing population and the development of a cash-crop economy in the northern provinces, has led to a progressive encroachment of cultivation into the grazing grounds of the cattle owners. Many nomadic Fulani and their herds have left; this is shown by the decline in the cattle population in the Kano and Sokoto provinces.

In striking contrast with the rest of the north, the cattle numbers in Bornu have increased steadily during the last two decades from 400,000 in the mid 1940 's to about $1,200,000$ in the early 1960 's. If the returns of the Rinderpest Eradication Campaign 1962/63 can be regarded as a more accurate approximation than these tax returns, the total cattle population is approaching two million. This rapid growth has been attributed to a steady influx of herds from less favourable areas; the cattle owners are attracted by the large stretches of relatively unrestricted grazing and during recent years by the construction of a large number of artesian boreholes, which provide ample water in a previously waterless area. This influx however has been accompanied by a rapid increase in cattle owned by the sedentary population since the proportion of nomadic cattle fell from 60 to $45 \%$ of the total during the last twenty years ${ }^{1}$.

Western Bornu differs from the central and north-eastern parts of the province in that:

1 Data obtained from unpublished records, Ministry of Animal and Forest Resources, Maiduguri and Biu. 
FIG. 4. A herd of Fulani cattle on trek

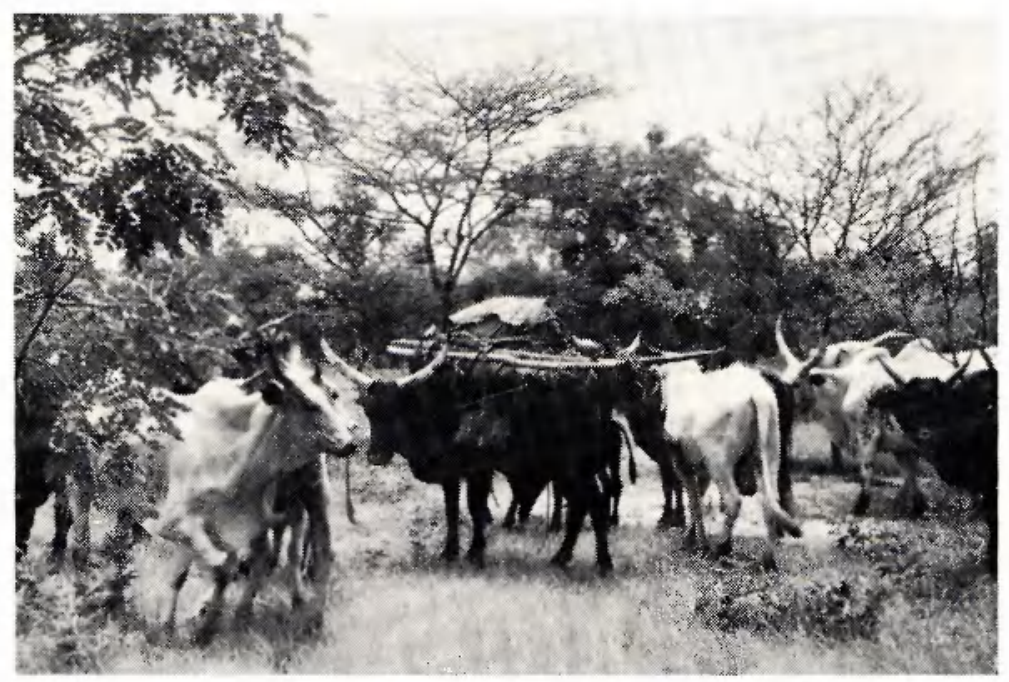

FIG. 5. Rinderpest inoculation camp near Meringa

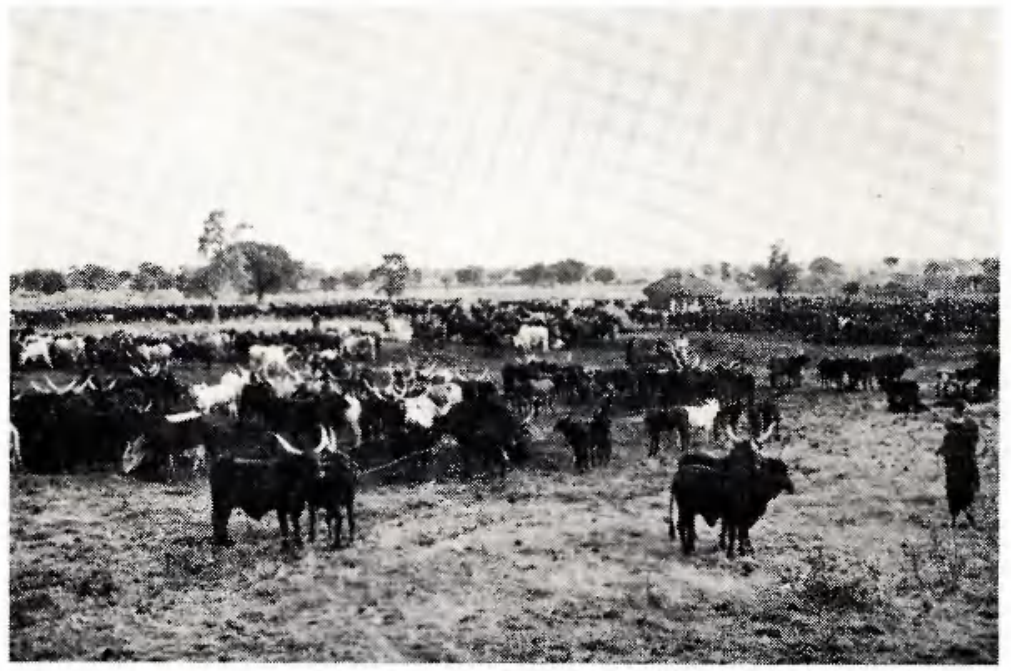


a. the area is within the grazing orbit of largely nomadic Fulani,

b. the proportion of "sedentary" cattle is low,

c. the transhumance pattern follows a north-south trend while elsewhere it is conditioned by Lage Chad, the River Yobe and the riverain areas in the Chad and Cameroon Republics,

d. so far it has not been subject to the problems now developing in north-east Bornu where the influx of large herds concentrated round the new boreholes has produced severe overgrazing and a sudden alteration of the traditional patterns of cattle movements.

\subsection{The Fulani in western Bornu}

One quarter of the population in the survey area are Fulani and they rank second after the Kanuri, the most populous and ruling tribe in the Bornu province (Anon, 1952). Only a small proportion of the Fulani are nomadic cattle owners; STENNING (1957) estimated that there are about 6,000 nomads in the Fune and Damaturu districts, amounting to about $4.5 \%$ of the total population. No data are available on the numbers of nomads in the southern part of the area.

In a study of the Wodaabe - the dominant nomadic Fulani group in the area STENNing (1957) has thrown much light on the socio-economic aspects of nomadic pastoralism. As they depend entirely on their cattle, their social life is determined by the needs of their herds.

The annual cycle of their movements is adapted to the seasonal variation in grazing and watering conditions. The actual route taken each year is modified to avoid the risks of diseases, tsetse and hyenas, whereas the distances covered and the location of camping places are governed by the conditions of the pasturelands and waterholes, the marketing facilities for dairy produce and the opportunities to kraal and feed their cattle on the stubble land of the sedentary farmers. During the height of the wet season when grass and water are abundant, the shifting of camps is necessary because the kraals become soggy and fly-infested, and frequent movements may also facilitate the evasion of the cattle tax. Camps are moved only over short distances and each group of families stays within a limited area.

The majority of Wodaabe who spend the wet season in the Damaturu/Fune area, move in the dry season to the Gujba and Mutwe plains and the Biu foothills; some groups venture further south to the flood plains of the River Gongola and its tributaries. The average distance between the extreme points of the journeys of 168 families is about $100 \mathrm{~km}$ with a range of 40 to $170 \mathrm{~km}$ (STENnING, 1957). The major attractions of the dry-season range are: -

a. the area is tsetse-free except along certain stretches of streams,

b. there is a fair proportion of swamp and flood-plain grassland,

c. the water supply is relatively favourable as some of the rivers are perennial or contain pools throughout the dry season,

d. there are large centres of sedentary population able to provide ample stubble grazing on guinea corn and bean fields as well as a ready market for dairy products.

\subsection{Cattle density and carrying capacity}

It is clear that the periodic movements bring about a seasonal fluctuation of the cattle density and as such constitute the response of the nomadic herdsmen to the variation in carrying capacity of the range.

The following figures are no more than a rough approximation of the total cattle population in the survey area; how the herds are distributed is not known. StenNing 
(1957) estimated that for the period 1946 to 1952 the number of cattle in the Fune/ Damaturu area averaged 57,000. Assuming an annual growth rate of $10 \%$ and allowing for tax evasion, the present population would lie between 100,000 and 150,000; the upper limit is still below the figure of 200,000 taken from the returns of the Rinderpest Eradication Campaign 1962/63 (FIG. 5). It can therefore be assumed that the maximum cattle density in the northern districts during the rainy season ranges between 20 and 30 head per $\mathrm{km}^{2}$. In the south (Babur district) the estimated density is about 20 head per $\mathrm{km}^{2}$. These figures are similar or somewhat higher than the densities of 15 to 25 head per $\mathrm{km}^{2}$ obtained in north-east Bornu.

There are no data to support an estimate of the population during the dry season; Srenning (1957) believed that in the Fune/Damaturu districts not more than $10 \%$ of the cattle which are taxed in the districts stay within the area. Allowing for a certain influx of herds from the north, a total population of between 10,000 and 20,000 head or a density of 2 to 4 per $\mathrm{km}^{2}$ may be acceptable.

Before raising the question whether the survey area as a whole is under- or overstocked, the carrying capacity of the range has to be considered. Here again data are scarce. Besides, unfortunately most of the available data are taken on a yearround basis without taking into account the seasonal fluctuations.

Gillet (1961), working in the northern part of the Chad Republic, estimates the carrying capacity of the annual grass savanna at 8 ha per animal with an upper and lower limit of 4 and 14 ha respectively. In a similar climate in the Mali and Niger Republics an average figure of $5 \mathrm{ha}$ is given with a seasonal variation of 0.5 to $1.0 \mathrm{ha}$ at the height of the rainy season and 10 ha in April and May (Doutresouille, 1952). High stocking of less than one ha per animal during the wet season obtains in the forest reserves in NW. Nigeria without causing apparent evidence of overgrazing (FIsHwICK, 1954). These high rates compare with dry-season rates of flood plain and swamp grasslands along the Niger (Doutresouille, 1952) and in the Sudan (RATTRAY, 1960). In the dry season under a rainfall of 625 to $1000 \mathrm{~mm}$, the uplands in the Sudan may carry one head per 12 ha (Rattray, 1960). According to RaIns (1963) deteriorated Northern-Guinea savanna will only support one animal per 12 ha, while sites from which tree vegetation is removed may carry one head per 2 ha under a proper system of management.

Summarising it appears that in the survey area a cattle density of 50 head per $\mathrm{km}^{2}$ in the rainy season and about 10 head per $\mathrm{km}^{2}$ during the dry season roughly corresponds to the carrying capacity of this type of range land. The assumption that during the wet season the grazing area in general is not overstocked, is supported by the fact that little evidence of overgrazing has been observed. Areas in which the herbaceous cover had been ruined by grazing and trampling were found only in the vicinity of Fulani camps and near sedentary settlements. Encroachment of Acanthospermum hispidum, Cassia tora and other weeds, which are indicators of overgrazing (FISHwick, 1954), is relatively rare and usually confined to secondary shrubland near villages, which is the communal grazing ground for "sedentary" flocks of goats and sheep.

The problem of stocking rates during the dry season is completely different. The carrying capacity of the range drops to 10 to $20 \%$ of that of the rainy season and the main sources of fodder for livestock are low-value foggage, young grass regrowth after burning, flood plain and swamp grassland, leaves and fruits of trees and shrubs, and stubble and crop residues. It is not known however, to what extent these various feeding stuffs contribute to the maintenance of the herds. Since numerous cattle die 
of starvation during the latter part of the dry season and the surviving ones are usually in very poor condition, it would appear that the dry season range fails to support the present cattle population at an adequate level of maintenance. The question arises whether a drastic reduction of the cattle numbers - assuming such measure could be enforced - would solve the problem. This depends entirely on whether the range is deficient in quantity or in quality of grazing. If the low feeding value is the main factor causing the starvation of the herds, the solution has to be sought in increasing the productivity of the range rather than in reducing cattle numbers.

\section{AETFAT/UNESCO Anon.}

BOUGHEY, A. S.

Chevalier, A.

Clayton, W. D.

Doutressouille, G. FISHWICK, R. W.

\section{Gillet, $H$.}

Hope, W. A.

KEAY, R. W. J.

\section{KLINKENBERG, K., P. R. TomLinson, G. M. Higgins and P. N. DE LEEUW \\ LEBRUN, J., and G. GilbERT \\ Pullan, R. A.}

RaINs, A. B.

RAMSAY, D. M., and P. N. DE LEEUW

Rattray, J. M.

SillaNs, R.

StenNing, D. J. ToMlinson, P. R.

VRIES, D. M. DE, and TH. A. DE BOER

\section{REF E R E N CES}

1959 Vegetation map of Africa. Oxford, Univ. Press.

1952 Population census of the northern region of Nigeria. Bull. Nos. 7 and 9, Lagos, Govt. Printer.

1957 The physiognomic delimitation of West African vegetation types. J. W. Afr. Sci. Ass. 3, 148-165.

1900 ex KEAY (1953b). Les zônes et les provinces botaniques de l'A.O.F. C.R.-Acad. Sci. 130.

1957 A preliminary report on the vegetation and soils of Northern Nigeria. Unpubl. rep., Min. Agric. Samaru.

1952 L'élevage au Soudan Français. E. Imbert, Alger.

1954 The control and improvement of grazing in the savanna forest areas of Northern Nigeria. Unpubl. rep. Min. Anim. and Forest Resources.

1961 Paturages sahéliens. Le Ranch de l'Ouadi Rime. J. Agric. Trop. Bot. Appl. 2, 10-11: 465-536.

1963 A report on the reconnaissance soil survey of part of western Bornu province. Soil Surv. Bull. (Samaru) No. 20.

1953a Isoberlinia woodlands in Nigeria and their flora. Lejeunia. $16,17-26$.

1953b An outline of Nigerian vegetation. 2nd ed. Lagos, Govt. Printer.

1963 The soils of the Middle Gongola region. Soil Surv. Bull. (Samaru) No. 21.

1954 Une classification écologique des forêts du Congo. INEAC, Bruxelles.

1962 The concept of the Middle Belt in Nigeria - an attempt at a climatic definition. J. Geog. Ass. Nigeria. 5, 1: 39-52.

1963 Grassland research in Northern Nigeria. Samaru Misc. Paper No. 1.

1964 An analysis of Nigerian savanna. part I. J. Ecol. 52, 233-254.

1960 The grass cover of Africa. FAO, Rome, Agric. Stud. No. 49.

1955 L'agriculture indigène, cause prémière de la transformation de la végétation en Afrique Centrale Francaise. J. Agric. Trop. Bot. Appl. 2, Nos. 5-6, 337-339.

1957 Savannah nomads. Oxford, Univ. Press.

1964 Classification of Northern Nigerian soils in terms of the legend of the Soils map of Africa, fourth approximation. African Soils. 9, 75-84.

1959 Methods used in botanical grassland research in the Netherlands and their aplication. Herb. abstr. 29, 1-7. 